\title{
A review on soil carbon accumulation due to the management change of major Brazilian agricultural activities
}

\author{
La Scala Júnior, N. *, De Figueiredo, EB. and Panosso, AR. \\ Faculdade de Ciências Agrárias e Veterinárias - FCAV, Universidade Estadual Paulista - UNESP, \\ Via de Acesso Professor Paulo Donato Castellane, s/n, CEP 14884-900, Jaboticabal, SP, Brazil \\ *e-mail: lascala@fcav.unesp.br
}

Received February 13, 2012 - Accepted April 10, 2012 - Distributed August 31, 2012

(With 5 figures)

\begin{abstract}
Agricultural areas deal with enormous $\mathrm{CO}_{2}$ intake fluxes offering an opportunity for greenhouse effect mitigation. In this work we studied the potential of soil carbon sequestration due to the management conversion in major agricultural activities in Brazil. Data from several studies indicate that in soybean/maize, and related rotation systems, a significant soil carbon sequestration was observed over the year of conversion from conventional to no-till practices, with a mean rate of $0.41 \mathrm{MgC} \mathrm{ha}^{-1} \mathrm{year}^{-1}$. The same effect was observed in sugarcane fields, but with a much higher accumulation of carbon in soil stocks, when sugarcane fields are converted from burned to mechanised based harvest, where large amounts of sugarcane residues remain on the soil surface $\left(1.8 \mathrm{Mg} \mathrm{Cha}^{-1}\right.$ year $\left.^{-1}\right)$. The higher sequestration potential of sugarcane crops, when compared to the others, has a direct relation to the primary production of this crop. Nevertheless, much of this mitigation potential of soil carbon accumulation in sugarcane fields is lost once areas are reformed, or intensive tillage is applied. Pasture lands have shown soil carbon depletion once natural areas are converted to livestock use, while integration of those areas with agriculture use has shown an improvement in soil carbon stocks. Those works have shown that the main crop systems of Brazil have a huge mitigation potential, especially in soil carbon form, being an opportunity for future mitigation strategies.
\end{abstract}

Keywords: greenhouse gas, mitigation strategies, soil carbon stock, carbon dioxide, agriculture.

\section{Uma revisão sobre o acúmulo de carbono no solo devido a mudança de manejo nas principais atividades agrícolas do Brasil}

\begin{abstract}
Resumo
Áreas agrícolas trocam enormes fluxos de $\mathrm{CO}_{2}$, oferecendo uma oportunidade para mitigar o efeito estufa. Neste trabalho, estudou-se o potencial de sequestro de carbono em razão da conversão no manejo das principais atividades agrícolas do Brasil. Dados de vários estudos têm indicado que no sistema soja/milho e nas respectivas rotações, ocorre um sequestro de carbono no solo significativo ao longo dos anos de conversão do plantio convencional para o plantio direto, com uma média de $0,41 \mathrm{Mg} \mathrm{C} \mathrm{ha}^{-1} \mathrm{ano}^{-1}$. O mesmo efeito tem sido observado nos canaviais, porém há maiores acúmulos de carbono no solo quando as áreas de cana-de-açúcar são convertidas da colheita baseada na queima para a mecanizada, em que grandes quantidades de palha são deixadas na superfície do solo $\left(1,8 \mathrm{Mg} \mathrm{C} \mathrm{ha}^{-1} \mathrm{ano}^{-1}\right)$. Esse maior potencial de acúmulo de carbono no solo nos canaviais, comparado com outras culturas, está diretamente relacionado com a maior produção primária dessa cultura. Apesar disso, muito desse potencial de sequestro é perdido, uma vez que os canaviais são reformados, sob preparo intensivo do solo. As áreas de pasto mostram uma depleção nos estoques de carbono, quando convertidas de áreas naturais; porém, a integração dessas áreas com agricultura pode promover o aumento nos estoques de carbono do solo. Os trabalhos têm mostrado que as principais atividades agrícolas do Brasil possuem um grande potencial de mitigação, especialmente na forma de acúmulo de carbono no solo, sendo uma oportunidade para estratégias futuras.
\end{abstract}

Palavras-chave: gás de efeito estufa, estratégias de mitigação, estoque de carbono do solo, dióxido de carbono, agricultura. 


\section{Introduction}

Brazilian agricultural activities play an important role in the employment opportunities and export balance of Brazil. In 2010, Brazilian agriculture-related exports attained a record of US\$ 76.4 billion, $18 \%$ higher than in 2008. Among the major goods exchanged are soybeans, sugar and meat, with Asia and Europe being the main targets and receiving 30 and $27 \%$ of Brazilian exports, respectively. Brazil is a significant world player in food production, having the potential to increase its present production without causing further pressure on natural areas, simply by expanding into degraded lands, especially those abandoned after pasture usage (Tollefson, 2010). One of the main concerns of Brazilian agriculture is the expansion of production while minimising its environmental impact, including greenhouse gas (GHG) emission, such as the ones associated with deforestation caused by the conversion of natural areas to agricultural use. The federal government of Brazil has implemented new programmes to reduce deforestation, favouring the reduction of GHG emissions with the expansion of agriculture on degraded land, of which at least 15 million hectares are available (Tollefson, 2010). Other initiatives have been implemented in Brazil, such as the expansion of no-tillage agriculture (cropping performed directly on crop residues without soil tillage) (Amado et al., 2006) and the reduction of sugarcane burning in the southeast (associated with sugarcane harvest), as well as the more rational use of land for agricultural production.

\section{Geographical Distribution of the Major Agricultural Activities in Brazil}

Figure 1 presents the spatial distribution of the main agricultural activities in Brazil considering the land use. Soybean and maize crops have been responsible for important changes in land use, which occurred first in southern Brazil with the implementation of no-tillage agriculture in the early 1970 s, reaching $80 \%$ of the agricultural areas in southern Brazil in the early 1980s (Mielniczuk et al., 2003). Then, annual cultures expanded to central Brazil, where, at first, they expanded under conventional tillage to most of the country. At the same time, a similar expansion was observed in livestock in central Brazil and most recently on the southern border of the Amazon region; in connection with livestock, it is estimated that approximately 100 million ha are degraded or abandoned (half of the pasture area), most of which is in central Brazil (Dias-Filho, 2005; Ronquim, 2007). The main agricultural activity that is not present in Amazonia is sugarcane growth; most of the production area for sugarcane is located in southern Brazil, especially in São Paulo state, with $50 \%$ of the Brazilian sugarcane cropped area and 4.4 million ha devoted to sugarcane production in 2010 and 2011.

World agriculture contributes to GHG emissions, with emissions estimated from 5.1 to $6.1 \mathrm{Gt} \mathrm{CO}_{2}$ eq year-1 (in 2005 ), or from 10 to $12 \%$ of the total annual anthropogenic greenhouse gas emission. The most recent data (from
2005) indicates that the majority of these emissions are related to methane $\left(\mathrm{CH}_{4}\right)$ and nitrous oxide $\left(\mathrm{N}_{2} \mathrm{O}\right)$ at 3.3

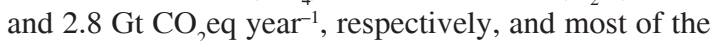
emissions are from livestock and synthetic fertiliser use, respectively. Despite the enormous $\mathrm{CO}_{2}$ fluxes between agricultural areas and the atmosphere (IPCC, 2007), the uncertainties associated with the possible benefits of conversion of annual crops and sugarcane to no-till and non-burn-based harvest, respectively, where large amounts of crop residues are left on the soil surface, must be recognised. In 2006, the IPCC suggested that conversion from conventional to no-till systems would be responsible for an increase from 10 to $22 \%$ in soil carbon stock but with an uncertainty of 4 to $8 \%$ depending on the climate zone, suggesting that caution is required when using these estimations (IPCC, 2006).

However, when the mitigation of GHG associated with agriculture is considered, $\mathrm{CO}_{2}$ plays an important role. Agricultural practices, such as reduction of the intensity and frequency of soil tillage and the maintenance of crop residues on the soil surface after harvest, have been indicated as simple options that would mitigate the greenhouse effect. In this respect, soil carbon sequestration would have the highest mitigation potential, contributing $89 \%$ of the total projection for the coming years in agricultural areas (IPCC, 2007). Reductions in direct $\mathrm{CH}_{4}$ and $\mathrm{N}_{2} \mathrm{O}$ emissions would result in mitigations of 9 and $2 \%$, respectively. This potential does not, however, consider the replacement of fossil fuels with biofuels, which would result in further mitigations associated with the transportation (mobile founts) and energy sectors, due to the replacement of coal with other fuels.

In recent studies, direct measurements of carbon capture by the biomass of northeastern agrosystems in several agricultural cultures in São Paulo state indicated a mean capture of $29.2 \mathrm{Mg} \mathrm{C} \mathrm{ha}^{-1}$ year $^{-1}$ in sugarcane crops, contributing to approximately $107 \mathrm{Mg} \mathrm{CO}_{2}$ ha $^{-1}$ year $^{-1}$ (Ronquim, 2007). As the total sugarcane agricultural area cropped in Brazil corresponds to almost eight million hectares (half of which is located in São Paulo state), the photosynthesis-related capture in this culture would be almost 0.9 Gton $\mathrm{CO}_{2}$ year ${ }^{-1}$ in the Brazilian sugarcanecropped lands alone. This value is almost $20 \%$ of the emissions associated with agriculture and $1.5 \%$ of the total anthropogenic emissions of GHG in the world (referring to the 2005 values). Such a sink would not necessarily result in atmospheric $\mathrm{CO}_{2}$ (or carbon) sequestration, as the final balance may be close to zero. The sugarcane crop is extracted, in many cases under a burn regime prior to harvest, and ethanol is produced, but this emits a significant amount of the $\mathrm{CO}_{2}$ sequestered from the atmosphere back into the atmosphere; the same likely occurs with sugar production. However, of the mean capture of $29.2 \mathrm{Mg} \mathrm{C} \mathrm{ha}^{-1}$ year $^{-1}$ in Brazilian sugarcane crops, at least $11 \%$ of this carbon is present in roots, leaves and parts of the plant that could be left in or lying on the soil, especially by mechanised harvest instead of burning. Changes in the management system, harvest or tillage would result in a significant 

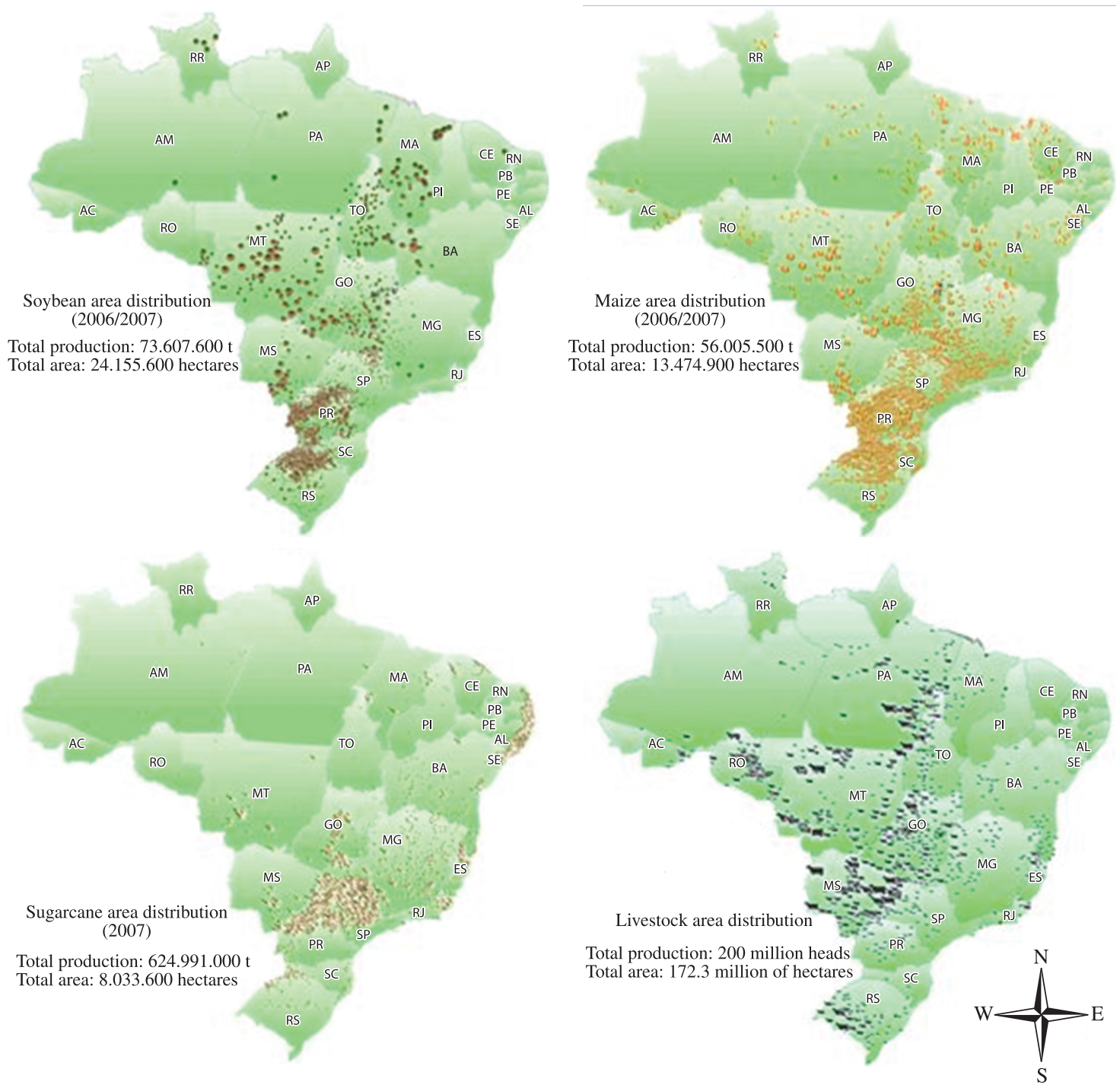

Figure 1. Spatial distribution, total production and cultivated area (hectares) of the main agricultural activities: soybean, maize, sugarcane and pasture (livestock) in Brazil. Total area and Production refers to 2010/2011. Source: CONAB - Companhia Nacional de Abastecimento.

increase in crop residue mass on the soil surface, nearly $12 \mathrm{t}$ per hectare each year (equivalent to five tons of $\mathrm{C}$ ), and in principle, this could result in soil $\mathrm{C}$ increases in those agricultural areas. Agricultural crops, especially sugarcane, which has a high capacity for absorbing $\mathrm{CO}_{2}$ from the atmosphere, could therefore be managed in a more rational way, resulting in a net storage of some of the $\mathrm{CO}_{2}$ captured by photosynthesis inside of the soil, helping in the mitigation of the greenhouse gas effect. In other agricultural crops such as soybean and maize, especially in southern Brazil, a great deal of effort has been exerted to characterise soil $\mathrm{C}$ sequestration after conversion from conventional to no-till, with the inclusion of crop rotation, especially with the use of leguminous crops. Those changes, in principle, are capable of changing the soil carbon regime, turning the soil into a sink for some of the carbon captured by photosynthesis.

Experiments performed in the last year have confirmed the capacity of agricultural production systems in Brazil to store $\mathrm{C}$ in the soil as well as in vegetation (in this case, primarily eucalyptus). This evidence is in accordance with IPCC (2006) methodology, which projects an increase of $11 \%$ in soil carbon stock in 20 years, when agricultural systems have been converted to retain large amounts of crop residues on the soil surface, as occurs in sugarcane upon conversion from burned to mechanised harvest. In addition, soil carbon sequestration would result from changes in the soil tillage system: once the agricultural system is converted from conventional to no-till, there could be an increase of $22 \pm 7 \%$ in soil C stocks in 20 years, according to the IPCC methodology. 
In several studies, researchers have calculated soil C stocks by means of soil organic carbon and soil density determinations, considering the appropriate depth. Those properties vary spatially and can have errors in their estimations. In addition, in $70 \%$ of the works considered in our study, soil organic $\mathrm{C}$ content was measured by means of dry combustion. According to Schrumpf et al. (2011), agricultural areas have smaller spatial variability in soil organic carbon and soil density in the first $10 \mathrm{~cm}$ of soil, especially when compared to pasture and natural vegetation areas, facilitating the detection of changes in soil $\mathrm{C}$ stocks with changes in management. The period needed to detect changes in soil $\mathrm{C}$ stocks would therefore depend on the spatial variability of soil properties, as well as their changes at a given depth. For those reasons, the present work was based on studies in which soil C stock changes were detected after at least three years of conversion to each of the systems considered.

\section{On the Soil Carbon Accumulation}

Figure 2 presents the geographical distribution of the main works considered for our analysis; these are publications where soil $\mathrm{C}$ sequestration studies were conducted in agricultural areas of Brazil. Those studies involved, necessarily, the direct measurement of the storage/loss of soil carbon due to changes in land use. Much interest in that issue has been seen recently in the literature, especially in agricultural areas of Brazil or in Amazonia, where large expanses of abandoned or degraded land exist. The same has occurred in southern Brazil when lands cropped with

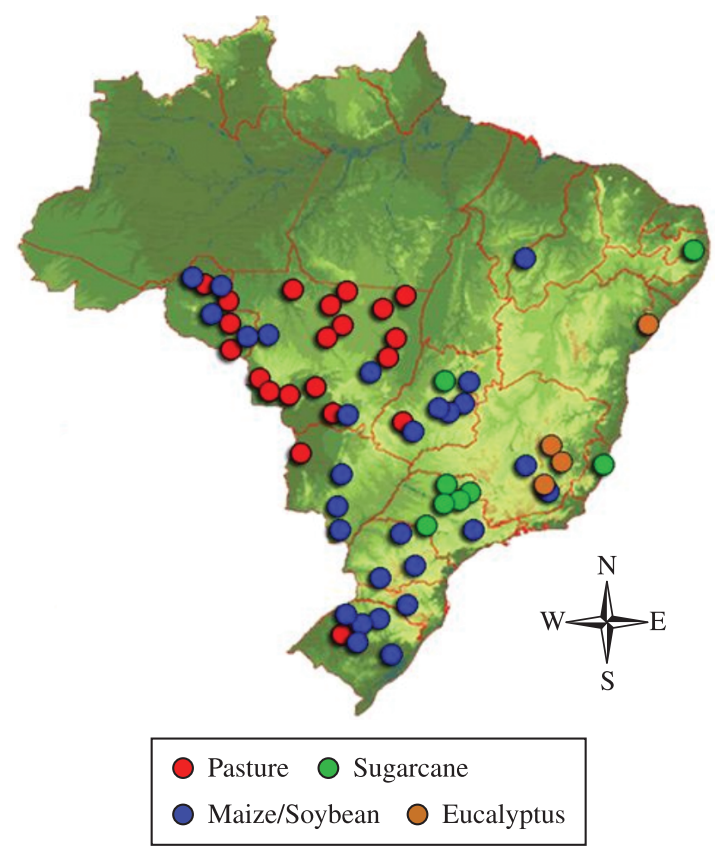

Figure 2. Spatial distribution of soil sequestration or sink potential studies of croplands in Brazil. Source: modified form Embrapa. soybean or maize have been converted to no-till. In southern Brazil, there is particular interest in soil carbon storage in sugarcane areas that are converted from burned to socalled green harvest (mechanised), where large amounts of crop residue are left on the soil surface. According to some studies, eucalyptus has a greater potential to stock atmospheric $\mathrm{C}$ in aerial biomass or in soil, mainly when associated with pasture or annual crops and especially in the conversion of degraded land to productive land and for renewable energy sources.

The works that we used as reference to obtain the data on soil $\mathrm{C}$ accumulation or storage once the main agricultural systems have been converted to more conservative practices are presented in Table 1, where the number of measurements performed in each of those works, the region location and the soil texture of the study are also shown.

\subsection{Annual crops: no tillage option}

Studies investigating soil $\mathrm{C}$ accumulation or storage in annual crops (soybean and maize), which were conducted mainly at depths of $0-30 \mathrm{~cm}$ (20\% of the studies) and $0-20 \mathrm{~cm}$ (70\% of the studies), have indicated mean soil C stock values of $0.41 \pm 0.06 \mathrm{Mg} \mathrm{C}^{-1}$ year $^{-1}$ (equivalent to $1.5 \mathrm{Mg} \mathrm{CO}_{2} \mathrm{ha}^{-1}$ year $^{-1}$ ) for sand and clay soils (Figure 3). This indicates that differences in soil texture did not result in significant differences in soil carbon sequestration, as similar accumulation rates were observed when more conservationist practices were implemented. In general, the primary factors contributing to the accumulation of $\mathrm{C}$ in the soil of annual crops are no-till practices and crop rotation sequences using leguminous plants, which remove atmospheric nitrogen via a symbiotic interaction, leaving large amounts of dry matter on the soil surface (Dieckow et al., 2005).

The conversion in this case would essentially require changing the tillage system from conventional, with successive soil tillage, to no-till with the addition of crop rotation and the resulting high residue input on the soil (Figure 3). It is noteworthy that the deviation of the C accumulation rate is small along the years of conversion to no-till, though some works have shown, for example, a depletion in soil $\mathrm{C}$ after 17 years of conversion. Many of the studies conducted in annual crops indicated a strong causeand-effect relationship between $\mathrm{C}$ sequestration potential and soil tillage practices, as well as the amount of crop residue input on the soil, especially in strategies combining crop rotation with no-till practices (Dieckow et al., 2009).

\subsection{Sugarcane fields: the green harvest option}

The soil $\mathrm{C}$ accumulation rates of sugarcane fields after conversion from burned to green harvest indicate much higher sequestration potential than those observed in soybean/maize crops (Figure 4). A mean rate of $1.87 \pm 0.20 \mathrm{Mg} \mathrm{C} \mathrm{ha}^{-1}$ year $^{-1}$ was observed; quite constant in all conversion years. Such C sequestration potential, observed in clay soils, is equivalent to $6,857 \mathrm{~kg} \mathrm{CO}_{2} \mathrm{ha}^{-1}$ year ${ }^{-1}$, which is extremely high and corresponds to $6.4 \%$ of the mean annual $\mathrm{CO}_{2}$ absorption of this crop every year (Ronquim, 2007). This amount is much 
Table 1. References of recent works with data on soil carbon accumulation due to changes in management of agricultural systems in Brazil

\begin{tabular}{|c|c|c|c|c|c|c|c|c|}
\hline \multirow{2}{*}{ Reference } & \multirow{2}{*}{$\begin{array}{c}\text { Number } \\
\text { of register }\end{array}$} & \multicolumn{5}{|c|}{ Region } & \multicolumn{2}{|c|}{ Textural } \\
\hline & & North & Northeast & Central & Southeast & South & Clay & Sand \\
\hline \multicolumn{9}{|c|}{ ( } \\
\hline Cerri et al. (2004) & 4 & & & & $x$ & & $x$ & $x$ \\
\hline Czycza (2009) & 2 & & & & $x$ & & $x$ & \\
\hline Feller et al. (2001) & 1 & & & & $x$ & & $x$ & \\
\hline Galdos et al. (2009) & 1 & & & & $x$ & & $x$ & \\
\hline Pinheiro et al. (2010) & 1 & & & & $x$ & & & $x$ \\
\hline Razafimbelo et al. (2006) & 1 & & & & $x$ & & $x$ & \\
\hline Resende et al. (2006) & 1 & & $x$ & & & & & $x$ \\
\hline Souza et al. (2005) & 1 & & & & $x$ & & & $x$ \\
\hline Szakács (2007) & 3 & & & $x$ & $x$ & & $x$ & \\
\hline \multicolumn{9}{|l|}{ Maize/Soybean } \\
\hline Amado et al. (2006) & 4 & & & & & $x$ & $x$ & $x$ \\
\hline Babujia et al. (2010) & 1 & & & & & $x$ & $x$ & \\
\hline Bayer et al. (2000) & 2 & & & & & $x$ & & $x$ \\
\hline Bayer et al. (2006) & 2 & & & $x$ & & & $x$ & \\
\hline Boddey et al. (2010) & 5 & & & & & $x$ & $x$ & \\
\hline Calegari et al. (2008) & 3 & & & & & $x$ & $x$ & \\
\hline Carvalho et al. (2009) & 1 & $x$ & & & & & $x$ & \\
\hline Castro-Filho et al. (1998) & 3 & & & & & $x$ & $x$ & \\
\hline Corazza et al. (1999) & 1 & & & $x$ & & & $x$ & \\
\hline Corbeels et al. (2006) & 1 & & & $x$ & & & $x$ & \\
\hline DeMaria et al. (1999) & 1 & & & & $x$ & & $x$ & \\
\hline Dieckow et al. (2005) & 4 & $x$ & & & & & $x$ & \\
\hline Dieckow et al. (2009) & 4 & & & $x$ & & $x$ & $x$ & $x$ \\
\hline Freitas et al. (2000) & 1 & & & $x$ & & & $x$ & \\
\hline Freixo et al. (2002) & 2 & & & & & $x$ & $x$ & \\
\hline Jantalia et al. (2007) & 1 & & & $x$ & & & $x$ & \\
\hline Leite et al. (2004) & 1 & & & & $x$ & & $x$ & \\
\hline Leite et al. (2009) & 2 & & $x$ & & $x$ & & $x$ & $x$ \\
\hline Lovato et al. (2004) & 2 & & & & & $x$ & & $x$ \\
\hline Maia et al. (2010) & 11 & $x$ & & $x$ & & & $x$ & $x$ \\
\hline Maltas et al. (2007) & 1 & & & $x$ & & & $x$ & \\
\hline Metay et al. (2007) & 1 & & & $x$ & & & $x$ & \\
\hline Oliveira et al. (2004) & 1 & & & $x$ & & & $x$ & \\
\hline Roscoe and Buurman (2003) & 1 & & & & $x$ & & $x$ & \\
\hline Sá et al. (2001) & 1 & & & & & $x$ & $x$ & \\
\hline Salton (2005) & 2 & & & $x$ & & & $x$ & \\
\hline Santos et al. (2011) & 4 & & & & & $x$ & $x$ & \\
\hline Sisti et al. (2004) & 2 & & & & & $x$ & $x$ & \\
\hline Zanatta et al. (2007) & 3 & & & $x$ & & & & $x$ \\
\hline \multicolumn{9}{|l|}{ Eucalyptus } \\
\hline Lima et al. (2006) & 2 & & & & $x$ & & $x$ & \\
\hline Stape et al. (2008) & 2 & & $x$ & & & & & $x$ \\
\hline \multicolumn{9}{|l|}{ Pasture } \\
\hline Cardoso et al. (2010) & 3 & & & $x$ & & & & $x$ \\
\hline Carvalho et al. (2010b) & 3 & $x$ & & $x$ & & & $x$ & \\
\hline Maia et al. (2009) & 31 & $x$ & & $x$ & & & $x$ & $x$ \\
\hline Nicoloso et al. (2008) & 9 & & & & & $\times$ & & $\times$ \\
\hline
\end{tabular}




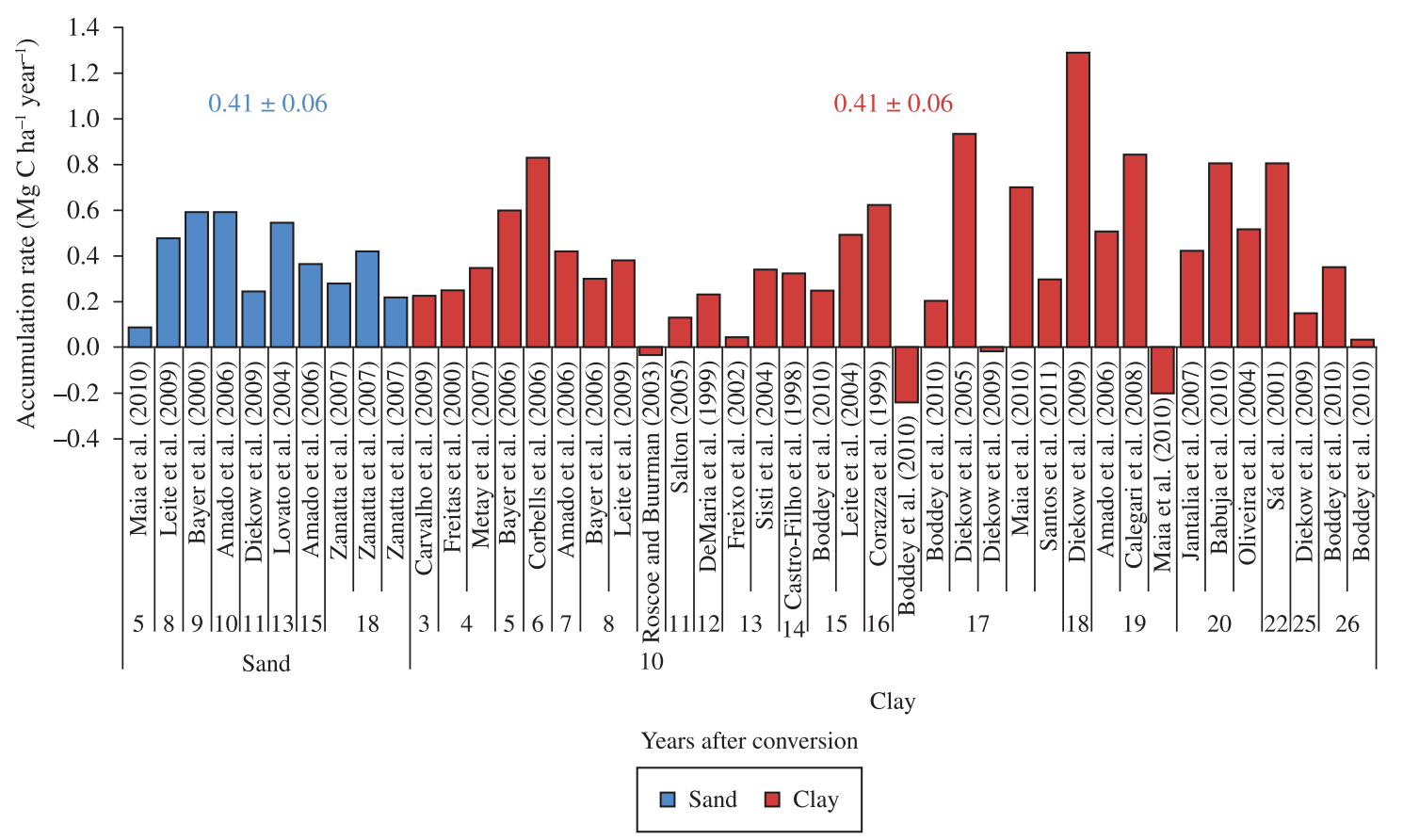

Figure 3. Accumulation or sink soil C potential $\left(\mathrm{Mg} \mathrm{C}\right.$ hectare ${ }^{-1}$ year $\left.{ }^{-1}\right)$ in annual crops (maize, soybean and crop rotation).

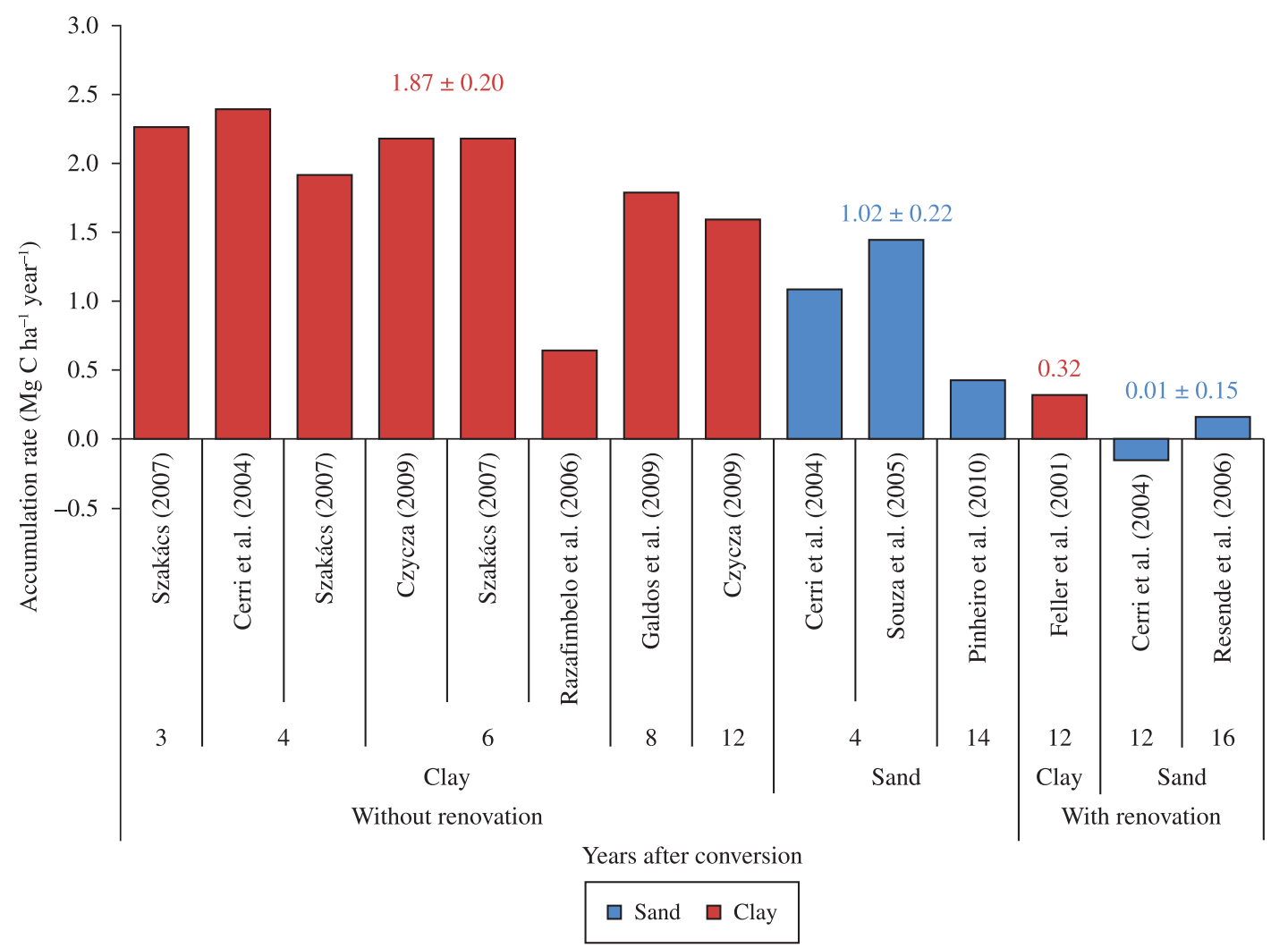

Figure 4. Accumulation or sink soil $\mathrm{C}$ potential $\left(\mathrm{Mg} \mathrm{C}\right.$ hectare ${ }^{-1}$ year $\left.^{-1}\right)$ in sugarcane areas after conversion from burn to green harvest. 
higher than inventory-based balances accounting for $\mathrm{N}_{2} \mathrm{O}$, $\mathrm{CH}_{4}$ and $\mathrm{CO}_{2}$ emissions from diesel fuel use, $\mathrm{N}$ fertiliser use and other emissions from sugarcane production in southern Brazil, which equalled 3,100 kg CO eq ha $^{-1}$ year $^{-1}$ (De Figueiredo and La Scala Junior, 2011). The use of burned harvesting for sugarcane would be the worst-case scenario for emissions. The $\mathrm{C}$ sequestration potential in the soils of sugarcane fields would be sufficient to compensate for all emissions derived from the use of machinery and synthetic fertilisers, resulting in a mitigation equivalent to $3,757 \mathrm{~kg} \mathrm{CO}_{2}$ ha $^{-1}$ year-1 $(6,857-3,100)$.

Two additional facts must also be considered. First, the carbon sequestration rate seen in sugarcane areas that are converted from burned to mechanised harvest is lower in sandy soils $\left(1.02 \pm 0.22 \mathrm{Mg} \mathrm{C} \mathrm{ha}^{-1}\right.$ year $\left.^{-1}\right)$. Second, few studies in the literature consider sugarcane field renovation, which occurs every five or six years after seeding; this causes the sequestration potential to be almost totally lost. Figure 4 present a single study from Feller (2001), that includes the soil carbon accumulation rate of $320 \mathrm{~kg} \mathrm{ha}^{-1}$ year ${ }^{-1}$ after 12 years of conversion from burned to green harvest, with one reform within this period. This rate would correspond to $1,733 \mathrm{~kg} \mathrm{CO}_{2} \mathrm{ha}^{-1}$ year $^{-1}$ sequestered from the atmosphere and incorporated in soil, in carbon form. As almost 4 million hectares in sugarcane fields are still cropped under burned harvest, the mitigation potential in the soil carbon accumulation potential would be close to $6.9 \mathrm{Tg} \mathrm{CO}_{2}$ per year, once all the Brazilian burned sugarcane areas would be converted to green harvest. Some scenarios are presented in Carvalho et al. (2010a), based on higher residues input and better management practices that would be adopted resulting in mitigation potential from 26.4 to $78 \mathrm{Tg}$ of soil $\mathrm{C}$ accumulated in a 20 -year period in sugarcane areas.

Recent studies have indicated that the simple conversion of sugarcane fields from burned to green harvest would not ensure significant increases in soil $\mathrm{C}$ stocks over time, as there is little understanding of the mechanisms in favour of sequestration or of what occurs in terms of soil C losses after soil tillage, at reform (La Scala et al., 2006). Experimental results from sugarcane fields indicate soil $\mathrm{CO}_{2}$ fluxes from 200 to $1,500 \mathrm{~kg} \mathrm{CO}_{2} \mathrm{ha}^{-1}$ induced at some weeks after tillage only (La Scala et al., 2008). Both the magnitude and the exponential decay of the emission over time after tillage indicate that labile carbon not previously accessible to microbial activity is made available by tillage and is then emitted to the atmosphere as $\mathrm{CO}_{2}$ (La Scala et al., 2006). This phenomenon has also been studied in annual cultures in southern Brazil, where high emissions with continuous decay over time have been observed after tillage (Chavez et al., 2009). We must therefore be cautious in stating that soil carbon sequestration occurs in sugarcane areas converted from burned to green harvest, which leaves high amounts of crop residue on the soil surface. It is imperative to consider the reform of sugarcane fields in those studies, as well as the contribution of emissions due to other mechanised operations in those areas. Other aspects of the stability of labile carbon, already investigated in southern Brazil (Dieckow et al., 2009), should also be incorporated in forthcoming studies with the aim of a better understanding of the possible causes and effects related to soil carbon sequestration in sugarcane areas. New strategies that would result in reduced frequency and intensity of soil tillage would be welcome, especially in sugarcane areas where the so-called no-till practice is not used, differently from annual cultures. However, recent publications have shown the high soil $\mathrm{C}$ sequestration potential of sugarcane areas.

\subsection{On the restore of soil carbon in pasture and eucalyptus lands}

In general, pasture areas are established where natural vegetation previously existed. There are several studies on changes of soil $\mathrm{C}$ stocks in such areas, including a dozen focussing on central Brazil (Figure 5). The studies can be divided into two groups based on the management regime and soil texture (clay and sand), in which changes in soil $\mathrm{C}$ stock were followed after conversion from natural vegetation to pasture or changes in stock due to the introduction of crop-pasture rotation practices. Recent results have shown that in areas where pasture was installed over natural vegetation, there was usually a reduction in soil C from 0.15 to $1.89 \mathrm{Mg} \mathrm{C} \mathrm{ha}^{-1}$ year $^{-1}(0-30 \mathrm{~cm}$ layer) in the initial years of conversion (Carvalho et al., 2010b; Maia et al., 2009). However, permanent pasture establishment on high-fertility soil could be responsible for a soil $\mathrm{C}$ sequestration rate of $0.72 \mathrm{Mg} \mathrm{C} \mathrm{ha}^{-1}$ year $^{-1}$ (Maia et al., 2009), as can also occur in permanent pasture areas managed with the addition of fertilisers and lime and with other practices. Among the management practices considered in pasture, higher soil $\mathrm{C}$ input resulted from the integration of crop-pasture production, where maize was rotated with soybeans and other crop rotations; this led to $\mathrm{C}$ sequestration rates from 0.82 to $1.35 \mathrm{Mg} \mathrm{C} \mathrm{ha}^{-1}$ year $^{-1}$ (Carvalho et al., 2010b). This is being considered as a new approach for degraded lands, increasing food production while mitigating the greenhouse effect.

Few works have studied carbon dynamics with soil $\mathrm{C}$ sequestration in eucalyptus-growing areas of Brazil. Eucalyptus cropping is expanding in Brazil, with the current area of six million hectares projected to increase to nine million hectares in 2020. Considering that this crop is quite efficient for atmospheric $\mathrm{CO}_{2}$ capture, large amounts of $\mathrm{C}$ can be stored in its biomass and soil, in accordance with IPCC (2006) methodology.

Eucalyptus forests established in tropical regions have the potential to fix approximately $90 \mathrm{t}$ of dry matter above ground per hectare, $49 \%$ of this being carbon, in the first 6 years. This would correspond to $162 \mathrm{t} \mathrm{CO}_{2} \mathrm{ha}^{-1}$ absorbed, including the carbon sequestered in roots, which is approximately $20 \%$ of that above ground (IPCC, 2006). The same methodology presents a sequestration rate for above-ground biomass in eucalyptus plantations in the tropical humid regions of South America of $7.84 \mathrm{t} \mathrm{C} \mathrm{ha}^{-1}$ year $^{-1}$ (Stape et al., 2004). This means that eucalyptus plantations associated with degraded pasture, where losses in soil 


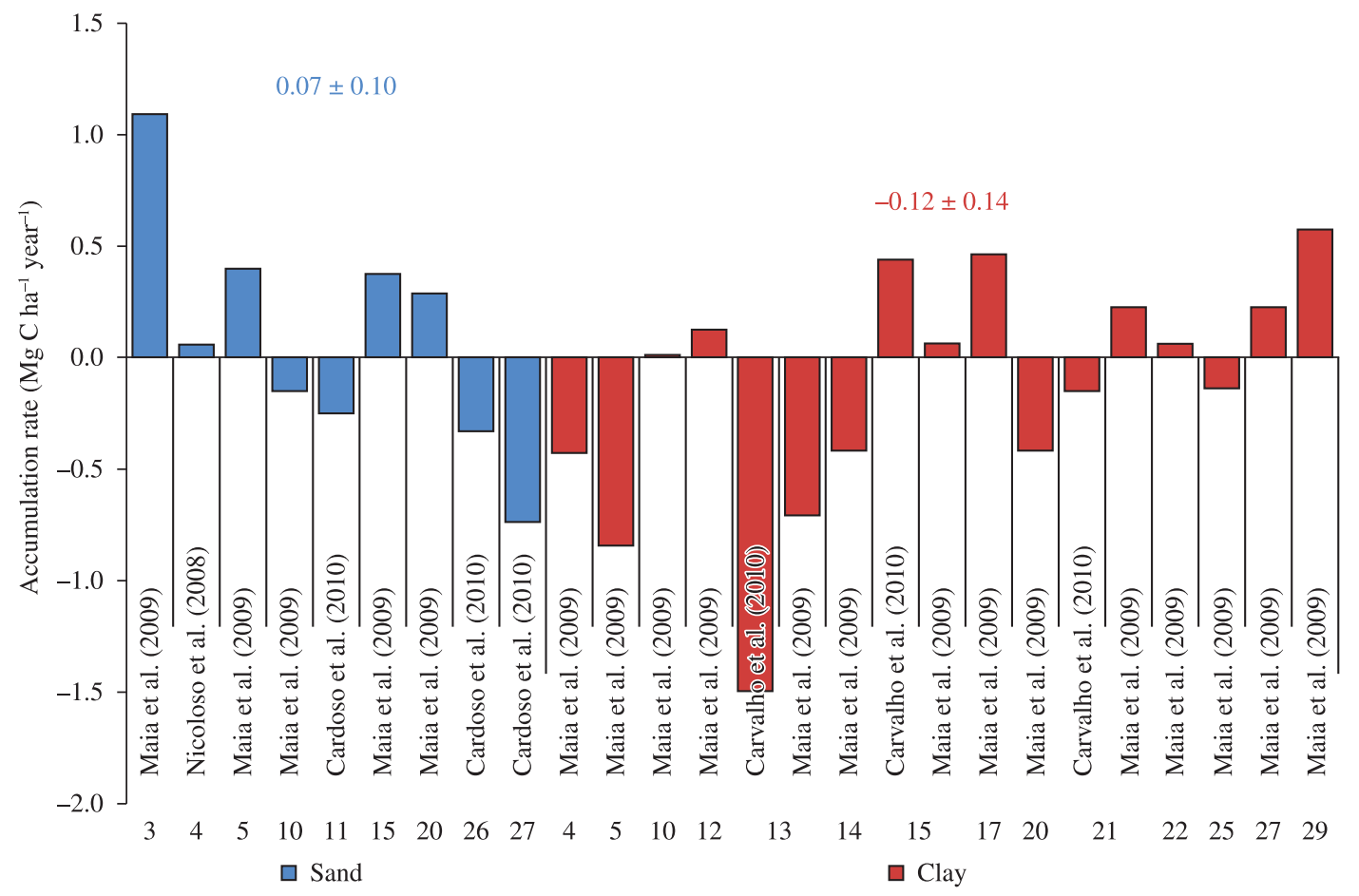

Years after conversion

$\square$ Sand $\square$ Clay

Figure 5. Accumulation or sink soil $\mathrm{C}$ potential $\left(\mathrm{Mg} \mathrm{C}\right.$ hectare ${ }^{-1}$ year $\left.^{-1}\right)$ in pasture under different management in Brazil.

carbon of as much as $1 \mathrm{t} \mathrm{ha}^{-1}$ year-1 $^{-1}$ have been reported, could absorb up to $28 \mathrm{t} \mathrm{CO}_{2} \mathrm{ha}^{-1}$ year ${ }^{-1}$ helping to mitigate the greenhouse effect.

\section{Final Remarks}

The changes in major agricultural activities in Brazil - soybean, maize and rotations, as well as sugarcane and pasture - have been evaluated in terms of their effects on soil carbon stocks. In general, this work indicates that no-till practices have resulted in a more constant rate of soil carbon sequestration after conversion from conventional tillage and that sugarcane crops have significant potential to increase soil carbon sequestration, though much of this is lost in the reform of sugarcane fields. Hence, the study of the soil $\mathrm{CO}_{2}$ emission induced by tillage in sugarcane areas is an important aspect which should be included in future investigations. The majority of the land used in Brazilian agriculture is for pasture, which has some soil carbon sequestration potential when pasture is integrated with agriculture; this also has the benefit of increasing agricultural production. Other recent results published in the literature (Carvalho et al., 2010a; Campos et al., 2011) indicate that there are even more appropriate management practices available that would result in the storage of absorbed atmospheric $\mathrm{CO}_{2}$ as soil carbon associated with the main agricultural activities in Brazil.

\section{REFERENCES}

AMADO, TJC., BAYER, C., CONCEIÇÃO, PC., SPAGNOLLO, E., DE CAMPOS, BHC. and DA VEIGA, M., 2006. Potential of carbon accumulation in no-till soils with intensive use and cover crops in southern Brazil. Journal of Environmental Quality, vol. 35, no. 4, p. 1599-1607. PMid:16825480. http://dx.doi.org/10.2134/ jeq2005.0233

BABUJIA, LC., HUNGRIA, M., FRANCHINI, JC. and BROOKES, PC., 2010. Microbial biomass and activity at various soil depths in a Brazilian oxisol after two decades of no-tillage and conventional tillage. Soil Biology \& Biochemistry, vol. 42, no. 12, p. 2174-2181. http://dx.doi.org/10.1016/j.soilbio.2010.08.013

BAYER, C., MARTIN-NETO, L., MIELNICZUK, J., PAVINATO, A. and DIECKOW, J., 2006. Carbon sequestration in two Brazilian Cerrado soils under no-till. Soil \& Tillage Research, vol. 86, no. 2, p. 237-245. http://dx.doi.org/10.1016/j.still.2005.02.023

BAYER, C., MIELNICZUK, J., AMADO, TJC., MARTIN-NETO, L. and FERNANDES, SV., 2000. Organic matter storage in a sandy clay loam Acrisol affected by tillage and cropping systems in southern Brazil. Soil \& Tillage Research, vol. 54, no. 1-2, p. 101-109. http://dx.doi.org/10.1016/S0167-1987(00)00090-8

BODDEY, RM., JANTALIA, CP., CONCEICAO, PC., ZANATTA, JA., BAYER, C., MIELNICZUK, J., DIECKOW, J., DOS SANTOS, HP., DENARDIN, JE., AITA, C., GIACOMINI, SJ., ALVES, BJR. and URQUIAGA, S., 2010. Carbon accumulation at depth in Ferralsols under zero-till subtropical agriculture. 
Global Change Biology, vol. 16, no. 2, p. 784-795. http://dx.doi. org/10.1111/j.1365-2486.2009.02020.x

CALEGARI, A., HARGROVE, WL., RHEINHEIMER, DD., RALISCH, R., TESSIER, D., DE TOURDONNET, S. and GUIMARAES, MD., 2008. Impact of long-term no-tillage and cropping system management on soil organic carbon in an Oxisol: A model for sustainability. Agronomy Journal, vol. 100, no. 4, p. 1013-1019. http://dx.doi.org/10.2134/agronj2007.0121

CAMPOS, BHC., AMADO, TJC., TORNQUIST, CG., NICOLOSO, RD. and FIORIN, JE., 2011. Long-term C-CO2 emissions and carbon crop residue mineralization in an oxisol under different tillage and crop rotation systems. Revista Brasileira de Ciência do Solo, vol. 35, no. 3, p. 819-832.

CARDOSO, EL., SILVA, MLN., SILVA, CA., CURI, N. and DE FREITAS, DAF., 2010. Carbon and nitrogen stocks in soil in native forests and pasture in the Pantanal biome, Brazil. Pesquisa Agropecuária Brasileira, vol. 45, no. 9, p. 1028-1035.

CARVALHO, JLN., AVANZI, JC., SILVA, MLN., DE MELLO, CR. and CERRI, CEP., 2010a. Potential of soil carbon sequestration in different biomes of Brazil. Revista Brasileira de Ciência do Solo, vol. 34, no. 2, p. 277-289. http://dx.doi.org/10.1590/S010006832010000200001

CARVALHO, JLN., CERRI, CEP., FEIGL, BJ., PICCOLO, MC., GODINHO, VP. and CERRI, CC., 2009. Carbon sequestration in agricultural soils in the Cerrado region of the Brazilian Amazon. Soil \& Tillage Research, vol. 103, no. 2, p. 342-349. http://dx.doi. org/10.1016/j.still.2008.10.022

CARVALHO, JLN., RAUCCI, GS., CERRI, CEP., BERNOUX, M., FEIGL, BJ., WRUCK, FJ. and CERRI, CC., 2010b. Impact of pasture, agriculture and crop-livestock systems on soil C stocks in Brazil. Soil \& Tillage Research, vol. 110, no. 1, p. 175-186. http://dx.doi.org/10.1016/j.still.2010.07.011

CASTRO-FILHO, C., MUZILLI, O. and PODANOSCHI, AL., 1998. Soil aggregate stability and its relation with organic carbon in a typic Haplorthox, as a function of tillage system, crop rotations and soil sample preparation. Revista Brasileira de Ciência do Solo, vol. 22, no. 3, p. 527-538.

CERRI, CC., BERNOUX, M., CERRI, CEP. and FELLER, C., 2004. Carbon cycling anal sequestration opportunities in South America: the case of Brazil. Soil Use and Management, vol. 20 , n., p. 248-254.

CHAVEZ, LF., AMADO, TJC., BAYER, C., LA SCALA, N., ESCOBAR, LF., FIORIN, JE. and DE CAMPOS, BHC., 2009. Carbon dioxide efflux in a Rhodic Hapludox as affected by tillage systems in southern Brazil. Revista Brasileira de Ciência do Solo, vol. 33, no. 2, p. 325-334. http://dx.doi.org/10.1590/ S0100-06832009000200010

CORAZZA, EJ., SILVA, JE., RESCK, DVS. and GOMES, AC., 1999. Behavior of different management systems as a source or sink of C-CO2 in ralation to cerrado type vegetation. Revista Brasileira de Ciência do Solo, vol. 23, no. 2, p. 425-432.

CORBEELS, M., SCOPEL, E., CARDOSO, A., BERNOUX, M., DOUZET, JM. and SIQUEIRA NETO, M., 2006. Soil carbon storage potential of direct seeding mulch-based cropping systems in the Cerrados of Brazil. Global Change Biology, vol. 12, no. 9, p. 1773-1787. http://dx.doi.org/10.1111/j.1365-2486.2006.01233.x

CZYCZA, RV., 2009. Soil organic matter quantity and quality under burned and unburned sugarcane harvesting system. Piracicaba: Universidade de São Paulo. 92p.
DE FIGUEIREDO, EB. and LA SCALA JUNIOR, N., 2011. Greenhouse gas balance due to the conversion of sugarcane areas from burned to green harvest in Brazil. Agriculture, Ecosystems and Environment, vol. 141, no. 1-2, p. 77-85. http://dx.doi. org/10.1016/j.agee.2011.02.014

DEMARIA, IC., NNABUDE, PC. and DE CASTRO, OM., 1999. Long-term tillage and crop rotation effects on soil chemical properties of a Rhodic Ferralsol in southern Brazil. Soil \& Tillage Research, vol. 51, no. 1-2, p. 71-79. http://dx.doi.org/10.1016/ S0167-1987(99)00025-2

DIAS-FILHO, MB., 2005. Degradação de pastagens: processo, causas, e estratégias de recuperação. 2nd ed. Belém: Embrapa Amazônia Oriental. 173 p.

DIECKOW, J., BAYER, C., CONCEICAO, PC., ZANATTA, JA., MARTIN-NETO, L., MILORI, DBM., SALTON, JC., MACEDO, MM., MIELNICZUK, J. and HERNANI, LC., 2009. Land use, tillage, texture and organic matter stock and composition in tropical and subtropical Brazilian soils. European Journal of Soil Science, vol. 60 , no. 2 , p. $240-249$. http://dx.doi.org/10.1111/j.13652389.2008.01101.x

DIECKOW, J., MIELNICZUK, J., KNICKER, H., BAYER, C., DICK, DP. and KOGEL-KNABNER, I., 2005. Soil C and N stocks as affected by cropping systems and nitrogen fertilisation in a southern Brazil Acrisol managed under no-tillage for 17 years. Soil \& Tillage Research, vol. 81, no. 1, p. 87-95. http://dx.doi. org/10.1016/j.still.2004.05.003

FELLER, C., 2001. Efeitos da colheita sem queima da cana-deaçúcar sobre a dinâmica do carbono e propriedades do solo. Piracicaba: Fapesp. 150 p. Final Report.

FREITAS, PL., BLANCANEAUX, P., GAVINELLI, E., LARRÉLARROUY, M. and FELLER, C., 2000. Nature and level of organic stock in clayey oxisols under different land use and management systems. Pesquisa Agropecuária Brasileira, vol. 35, no. 1, p. 157-170. http://dx.doi.org/10.1590/S0100-204X2000000100018

FREIXO, AA., MACHADO, P., DOS SANTOS, HP., SILVA, CA. and FADIGAS, FD., 2002. Soil organic carbon and fractions of a Rhodic Ferralsol under the influence of tillage and crop rotation systems in southern Brazil. Soil \& Tillage Research, vol. 64, no. 3-4, p. 221-230. http://dx.doi.org/10.1016/S0167-1987(01)00262-8

GALDOS, MV., CERRI, CC., CERRI, CEP., PAUSTIAN, K., VAN ANTWERPEN, R., 2009. Simulation of Soil Carbon Dynamics under Sugarcane with the CENTURY Model. Soil Science Society of America Journal, vol. 73, no. 3, p. 802-811. http://dx.doi.org/10.2136/sssaj2007.0285

Intergovernmental Panel on Climate Change - IPCC, 2006. Cropland. In EGGLESTON, HS., BUENDIA, L., MIWA, K., NGARA, T., TANABE, K. (Eds.). Guidelines for National Greenhouse Gas Inventories. Hayama: IGES. vol. 4: Agriculture, Forestry and Other Land Use, chapt. 5, p. 5.1-5.66.

Intergovernmental Panel on Climate Change - IPCC, 2007. Climate change 2007: Mitigation of Climate Change. New York: Cambridge University Press. 851 p.

JANTALIA, CP., RESCK, DVS., ALVES, BJR., ZOTARELLI, L., URQUIAGA, S. and BODDEY, RM., 2007. Tillage effect on $\mathrm{C}$ stocks of a clayey Oxisol under a soybean-based crop rotation in the Brazilian Cerrado region. Soil \& Tillage Research, vol. 95, no. 1-2, p. 97-109. http://dx.doi.org/10.1016/j.still.2006.11.005

LA SCALA, N., BOLONHEZI, D. and PEREIRA, GT., 2006. Short-term soil $\mathrm{CO} 2$ emission after conventional and reduced 
tillage of a no-till sugar cane area in southern Brazil. Soil \& Tillage Research, vol. 91, no. 1-2, p. 244-248. http://dx.doi. org/10.1016/j.still.2005.11.012

LA SCALA, N., LOPES, A., SPOKAS, K., BOLONHEZI, D., ARCHER, D. and REICOSKY, DC., 2008. Short-term temporal changes of soil carbon losses after tillage described by a first-order decay model. Soil \& Tillage Research, vol. 99, p. 108-118. http:// dx.doi.org/10.1016/j.still.2008.01.006

LEITE, LFC., DORAISWAMY, PC., CAUSARANO, HJ., GOLLANY, HT., MILAK, S. and MENDONCA, ES., 2009. Modeling organic carbon dynamics under no-tillage and plowed systems in tropical soils of Brazil using CQESTR. Soil \& Tillage Research, vol. 102, no. 1, p. 118-125. http://dx.doi.org/10.1016/j. still.2008.08.003

LEITE, LFC., MENDONCA, ED., MACHADO, P., FERNANDES, EI. and NEVES, HCL., 2004. Simulating trends in soil organic carbon of an Acrisol under no-tillage and disc-plow systems using the Century model. Geoderma, vol. 120, no. 3-4, p. 283-295. http://dx.doi.org/10.1016/j.geoderma.2003.09.010

LIMA, AMN., SILVA, IR., NEVES, JCL., NOVAIS, RF., BARROS, NF., MENDONCA, ES., SMYTH, TJ., MOREIRA, MS. and LEITE, FP., 2006. Soil organic carbon dynamics following afforestation of degraded pastures with eucalyptus in southeastern Brazil. Forest Ecology and Management, vol. 235, no. 1-3, p. 219-231. http:// dx.doi.org/10.1016/j.foreco.2006.08.331

LOVATO, T., MIELNICZUK, J., BAYER, C. and VEZZANI, F., 2004. Carbon and nitrogen addition related to stocks of these elements in soil and corn yield under management systems. Revista Brasileira de Ciência do Solo, vol. 28, p. 175-187.

MAIA, SMF., OGLE, SM., CERRI, CEP. and CERRI, CC., 2009. Effect of grassland management on soil carbon sequestration in Rondonia and Mato Grosso states, Brazil. Geoderma, vol. 149, no. 1-2, p. 84-91. http://dx.doi.org/10.1016/j.geoderma.2008.11.023

-, 2010. Soil organic carbon stock change due to land use activity along the agricultural frontier of the southwestern Amazon, Brazil, between 1970 and 2002. Global Change Biology, vol. 16, no. 10, p. 2775-2788. http://dx.doi.org/10.1111/j.1365-2486.2009.02105.x

MALTAS, A., CORBEELS, M., SCOPEL, E., OLIVER, R., DOUZET, JM., DA SILVA, FAM. and WERY, J., 2007. Long-term effects of continuous direct seeding mulch-based cropping systems on soil nitrogen supply in the Cerrado region of Brazil. Plant and Soil, vol. 298, no. 1-2, p. 161-173. http://dx.doi.org/10.1007/ s11104-007-9350-1

METAY, A., MOREIRA, JAA., BERNOUX, M., BOYER, T., DOUZET, JM., FEIGL, B., FELLER, C., MARAUX, F., OLIVER, R. and SCOPEL, E., 2007. Storage and forms of organic carbon in a no-tillage under cover crops system on clayey Oxisol in dryland rice production (Cerrados, Brazil). Soil \& Tillage Research, vol. 94, no. 1, p. 122-132. http://dx.doi.org/10.1016/j.still.2006.07.009

MIELNICZUK, J., BAYER, C., VEZZANI, FM., LOVATO, T., FERNANDES, F. F. and DEBARBA, L., 2003. Manejo de solo e culturas e sua relação com os estoques de carbono e nitrogênio do solo. In CURI, N., MARQUES, JJ., GUILHERME, LRG., LIMA, JM., LOPES, AS., ALVAREZ V., VH. Tópicos em Ciência do Solo. Viçosa: Sociedade Brasileira de Ciência do Solo. vol. 3, p. $209-248$.

NICOLOSO, RD., LOVATO, T., AMADO, TJC., BAYER, C. and LANZANOVA, ME., 2008. Soil organic carbon budget under crop-livestock integration in southern Brazil. Revista Brasileira de Ciência do Solo, vol. 32, no. 6, p. 2425-2433.
OLIVEIRA, GC., DIAS JÚNIOR, MS., RESCK, DVS. and CURI, N., 2004. Chemistry and physical-hydric characterization of a red latosol after 20 years os different soil use and management. Revista Brasileira de Ciência do Solo, vol. 28, no. 2, p. 327-336. http://dx.doi.org/10.1590/S0100-06832004000200011

PINHEIRO, EFM., LIMA, E., CEDDIA, MB., URQUIAGA, S., ALVES, BJR. and BODDEY, RM., 2010. Impact of pre-harvest burning versus trash conservation on soil carbon and nitrogen stocks on a sugarcane plantation in the Brazilian Atlantic forest region. Plant and Soil, vol. 333, no. 1-2, p. 71-80. http://dx.doi. org/10.1007/s11104-010-0320-7

RAZAFIMBELO, T., BARTHES, B., LARRE-LARROUY, MC., DE LUCA, EF., LAURENT, JY., CERRI, CC. and FELLER, C., 2006. Effect of sugarcane residue management (mulching versus burning) on organic matter in a clayey Oxisol from southern Brazil. Agriculture Ecosystems \& Environment, vol. 115, no. 1-4, p. 285-289. http://dx.doi.org/10.1016/j.agee.2005.12.014

RESENDE, AS., XAVIER, RP., DE OLIVEIRA, OC., URQUIAGA, S., ALVES, BJR. and BODDEY, RM., 2006. Long-term effects of pre-harvest burning and nitrogen and vinasse applications on yield of sugar cane and soil carbon and nitrogen stocks on a plantation in Pernambuco, NE Brazil. Plant and Soil, vol. 281, no. 1-2, p. 339-351. http://dx.doi.org/10.1007/s11104-005-4640-y

RONQUIM, CC., 2007. Dinâmica espaço temporal do carbono aprisionado na fitomassa dos agroecossistemas no nordeste do Estado de São Paulo. Campinas: Embrapa Monitoramento por Satélite. 52 p.

ROSCOE, R. and BUURMAN, P., 2003. Tillage effects on soil organic matter in density fractions of a Cerrado Oxisol. Soil \& Tillage Research, vol. 70, no. 2, p. 107-119. http://dx.doi. org/10.1016/S0167-1987(02)00160-5

SÁ, JCM., CERRI, CC., DICK, A., LAL, R., VENSKE-FILHO, SP., PICCOLO, MC. and FEIGL, BE., 2001. Organic matter dynamics and carbon sequestration rates for a tillage chro-nosequence in a Brazilian oxisol. Soil Science Society of America Journal, vol. 65, no. 5, p. 1486-1499. http://dx.doi.org/10.2136/sssaj2001.6551486x

SALTON, JC., 2005. Organic matter and soil aggreration under crop-pasture rotation in tropical environment. Porto Alegre: Universidade Federal do Rio Grande do Sul. 158 p.

SANTOS, NZ., DIECKOW, J., BAYER, C., MOLIN, R., FAVARETTO, N., PAULETTI, V. and PIVA, JT., 2011. Forages, cover crops and related shoot and root additions in no-till rotations to $\mathrm{C}$ sequestration in a subtropical Ferralsol. Soil \& Tillage Research, vol. 111, no. 2, p. 208-218. http://dx.doi.org/10.1016/j. still.2010.10.006

SCHRUMPF, M., SCHULZE, ED., KAISER, K. and SCHUMACHER, J., 2011. How accurately can soil organic carbon stocks and stock changes be quantified by soil inventories? Biogeosciences, vol. 8, no. 1, p. 1193-1212. http://dx.doi. org/10.5194/bg-8-1193-2011

SISTI, CPJ., DOS SANTOS, HP., KOHHANN, R., ALVES, BJR., URQUIAGA, S. and BODDEY, RM., 2004. Change in carbon and nitrogen stocks in soil under 13 years of conventional or zero tillage in southern Brazil. Soil \& Tillage Research, vol. 76, no. 1, p. 39-58. http://dx.doi.org/10.1016/j.still.2003.08.007

SOUZA, ZM., PRADO, RM., PAIXÃO, ACS. and CESARIN, LG., 2005. Sistemas de colheita e manejo da palhada de cana-deaçúcar. Pesquisa Agropecuária Brasileira, vol. 40, no. 3, p. 271-278. 
STAPE, JL., BINKLEY, D. and RYAN, MG., 2004. Eucalyptus production and the supply, use and efficiency of use of water, light and nitrogen across a geographic gradient in Brazil. Forest Ecology and Management, vol. 193, no. 1-2, p. 17-31. http:// dx.doi.org/10.1016/j.foreco.2004.01.020

-, 2008. Production and carbon allocation in a clonal Eucalyptus plantation with water and nutrient manipulations. Forest Ecology and Management, vol. 255, no. 3-4, p. 920-930. http://dx.doi. org/10.1016/j.foreco.2007.09.085
SZAKÁCS, GGJ., 2007. Soil carbon stocks and soil aggregation under sugar cane: the effect of green trash and climate in Central and Southern Brazil. Piracicaba: Universidade de São Paulo. 105p.

TOLLEFSON, J., 2010. Food The Global Farm. Nature, vol. 466, no. 7306, p. 554-556. PMid:20671690. http://dx.doi. org/10.1038/466554a

ZANATTA, JA., BAYER, C., DIECKOW, J., VIEIRA, FCB. and MIELNICZUK, J., 2007. Soil organic carbon accumulation and carbon costs related to tillage, cropping systems and nitrogen fertilization in a subtropical Acrisol. Soil \& Tillage Research, vol. 94 , no. 2, p. 510-519. 
